\title{
Denaturation Kinetics of Whey Protein Isolate Solutions and Fouling Mass Distribution in a Plate Heat Exchanger
}

\author{
Marwa Khaldi, ${ }^{1,2,3}$ Gilles Ronse, ${ }^{1,2}$ Christophe André, ${ }^{1,2,4}$ \\ Pascal Blanpain-Avet, ${ }^{1,2}$ Laurent Bouvier, ${ }^{1,2}$ Thierry Six, ${ }^{1,2}$ Saloua Bornaz, \\ Thomas Croguennec, ${ }^{6}$ Romain Jeantet, ${ }^{6}$ and Guillaume Delaplace ${ }^{1,2}$ \\ ${ }^{1}$ INRA, UR638, Processus aux Interfaces et Hygiène des Matériaux (PIHM), BP 20039, 369 rue Jules Guesde, \\ 59651 Villeneuve d'Ascq, France \\ ${ }^{2}$ Unité de Matériaux et Transformations (UMET), UMR CNRS 8207, Université de Lille 1, 59650 Villeneuve d'Ascq, France \\ ${ }^{3}$ Institut National Agronomique de Tunisie, 43 avenue Charles Nicolle, 1082 Tunis Mahrajène, Tunisia \\ ${ }^{4}$ HEI, Laboratoire de Génie des Procédés, 59046 Lille, France \\ ${ }^{5}$ Ecole Supérieure des Industries Alimentaires de Tunis, 58 avenue Alain Savary, 1003 Tunis El Khadra, Tunisia \\ ${ }^{6}$ INRA, AGROCAMPUS OUEST, UMR 1253, 35042 Rennes, France
}

Correspondence should be addressed to Marwa Khaldi; marwa.khaldi@lille.inra.fr

Received 23 July 2015; Revised 9 October 2015; Accepted 11 October 2015

Academic Editor: Xijun $\mathrm{Hu}$

Copyright (C) 2015 Marwa Khaldi et al. This is an open access article distributed under the Creative Commons Attribution License, which permits unrestricted use, distribution, and reproduction in any medium, provided the original work is properly cited.

Few investigations have attempted to connect the mechanism of dairy fouling to the chemical reaction of denaturation (unfolding and aggregation) occurring in the bulk. The objective of this study is to contribute to this aspect in order to propose innovative controls to limit fouling deposit formation. Experimental investigations have been carried out to observe the relationship between the deposit mass distribution generated in plate heat exchangers (PHE) by a whey protein isolate (WPI) mainly composed of $\beta$ lactoglobulin $(\beta-\mathrm{Lg})$ and the ratio between the unfolding and aggregation rate constants. Experiments using a PHE were carried out at a pilot scale to identify the deposit distribution of a model fouling solution with different calcium contents. In parallel, laboratory experiments were performed to determine the unfolding/aggregation rate constants. Data analysis showed that (i) $\beta$-Lg denaturation is highly dependent on the calcium content, (ii) for each fouling solution, irrespective of the imposed temperature profile, the deposit mass in each channel and the ratio between the unfolding and aggregation rate constants seem to be well correlated. This study demonstrates that both the knowledge of the thermal profile and the $\beta$-Lg denaturation rate constants are required in order to predict accurately the deposit distribution along the PHE.

\section{Introduction}

In the dairy industry, heat treatments are carried out in order to ensure food security and to impart several functionalities to milk and its derivatives, like thermal stability, viscosity, or gelation [1-3].

Fouling deposit formation on heat exchanger surfaces is a major industrial problem of milk processing plants, which involves frequent cleaning of the installations, thereby resulting in excessive rinsing water and harsh chemicals use. A number of studies have reported the drastic economic costs of fouling. Fouling and the resulting cleaning of the process equipment account for about $80 \%$ of the total production costs [4]. According to Tay and Yang [5], the total heat exchanger fouling costs for highly industrialized countries are about $0.25 \%$ of the Gross National Product. In the USA, total fouling costs have been estimated as US $\$ 7$ billion [6].

Milk fouling deposit is complex in nature. Deposit is formed by a mixture of inorganic salts (mainly calcium) and proteins (largely whey proteins). The key role played by $\beta-\mathrm{Lg}$ has been recognized in most milk fouling studies [7-9].

The fouling mechanisms are complicated and involve chemical reactions and heat and mass transfer processes [7-10]. The deposition is a result of a number of stages 
occurring at both the bulk volume and the surface [11] as follows:

(i) unfolding and aggregation of proteins in the bulk;

(ii) transport of the unfolded and aggregated proteins to the surface;

(iii) surface reactions resulting in incorporation of protein into the deposit layer;

(iv) possible reentrainment or removal of deposit toward the bulk.

At the state of the art, the possible limiting processes controlling fouling phenomena (bulk reaction regarding the temperature profiles, surface reaction concerning the flow conditions, and mass transfer of the different protein species occurring in the bulk) are not clearly elucidated and ambiguity on foulant precursor (unfolded and/or aggregated species) also exists.

Belmar-Beiny et al. [11] and Schreier and Fryer [12] proposed that fouling was dependent on the bulk and surface reactions and not on the mass transfer. Belmar-Beiny et al. [11], using a tubular heat exchanger fouled with whey protein concentrate, correlated the mass deposit with the volume of fluid hot enough to produce unfolded and aggregated proteins. This result highlighted the importance of denaturation reactions in the bulk but does not allow concluding specifically which protein species are dominant on fouling. On the other hand, van Asselt et al. [13] stated that $\beta$-Lg aggregates are not involved in the fouling reactions.

So, there is still a lack of knowledge between the chemical reactions occurring in the bulk (unfolding and aggregation of $\beta$-Lg for a given temperature profile), their consequences on foulant precursor concentrations, and the extent of fouling.

In this study, we propose to partially fill this gap by investigating the chemical reactions of $\beta$-Lg denaturation occurring in the bulk, for two WPI model fouling solutions, and their link with the fouling phenomena.

The main objective of this work is to investigate whether a relationship can be established between the distribution of the dry fouling deposit mass in each PHE channel and the $\beta$-Lg rate constants (computed at the mean channel temperature) of the model fouling solutions, for various operating conditions (processing parameters inducing various thermal profiles).

\section{Materials and Methods}

2.1. Fouling Model Fluids. The model fluids used in this study were reconstituted from WPI Promilk 852FB1 supplied by Ingredia (France). The composition of the powder is shown in Table 1.

In each experiment, $1 \%(\mathrm{w} / \mathrm{w}) \quad \beta$-Lg solutions with various calcium concentrations were prepared by mixing $10 \mathrm{~g}$ of WPI powder in $1 \mathrm{~L}$ reverse osmosis water at room temperature. Then, different quantities of a molar calcium chloride (anhydrous, 96\%, Acros Organics, Thermo Fisher Scientific, Waltham, MA, USA) solution were added to the $\beta$-Lg solution to obtain the two model fouling solutions
TABLE 1: Composition of WPI powder.

\begin{tabular}{lc}
\hline Component & $\begin{array}{c}\text { Promilk 852FB1 } \\
(\% \mathrm{w} / \mathrm{w})\end{array}$ \\
\hline Total proteins & 80.1 \\
$\beta$-Lg & 66.0 \\
$\alpha$-lactalbumin & 13.3 \\
Fat & 1 \\
Lactose & 11 \\
Minerals & 2.9 \\
\hline
\end{tabular}

containing, respectively, (i) $1 \%(\mathrm{w} / \mathrm{w}) \beta-\mathrm{Lg}$ and $100 \mathrm{ppm}$ of total calcium and (ii) $1 \%(\mathrm{w} / \mathrm{w}) \beta-\mathrm{Lg}$ and $120 \mathrm{ppm}$ of total calcium. The $\mathrm{pH}$ of these fouling solutions was close to 6.8 .

Only a small range of calcium content was studied because it is admitted that a very slight chemical variation results in a large variation in the fouling formation [14, 15]. The calcium concentration of the two model solutions was determined by atomic absorption spectrometry with a Spectro AA 55B apparatus (Varian, Palo Alto, CA, USA).

\subsection{Thermal Denaturation Experiments at Constant Holding} Temperature. All thermal denaturation experiments were conducted on twelve samples of $2 \mathrm{~mL}$ that were put in stainless steel tubes ( $350 \mathrm{~mm}$ length, $10 \mathrm{~mm}$ core diameter, $1 \mathrm{~mm}$ wall thickness, and $0.3 \mu \mathrm{m}$ surface roughness), to be closer to the actual conditions on the PHE. The investigated temperatures was ranged from 65 to $92^{\circ} \mathrm{C}$.

Before submitting samples to the desired holding temperature, the samples were preheated at $60^{\circ} \mathrm{C}$ for the range of desired temperatures below $80^{\circ} \mathrm{C}$ and $65^{\circ} \mathrm{C}$ for the range of desired temperatures over $80^{\circ} \mathrm{C}$ in a first water bath. The choice of this water bath temperature is not trivial. The $\beta-\mathrm{Lg}$ denaturation temperature is estimated at about $77^{\circ} \mathrm{C}[16,17]$.

The temperature increase from the preheating temperature to the desired holding temperature was performed by placing the samples in a second water bath whose temperature was maintained until $20^{\circ} \mathrm{C}$ higher than the holding temperature. The second water bath was used in order to reduce the heat increase time and the denaturation level before sampling. The first sample, corresponding to time zero, was taken when the sample temperature was equal to the desired holding value.

The eleven other samples were maintained during a time sufficient in a third water bath, taken off at different times, and cooled down immediately in a beaker with melting ice to stop further $\beta$ - $\operatorname{Lg}$ denaturation. The third water bath was fixed $2^{\circ} \mathrm{C}$ higher than the desired temperature. From the second to the third water bath, the heating rate is ranged between 0.83 and $0.93^{\circ} \mathrm{C} \cdot \mathrm{s}^{-1}$.

The temperature profile in samples placed in the three water baths was determined using a sensor connected to a temperature measurement acquisition system, placed in a stainless steel tube filled with water (Figure 1).

2.3. HPLC Analysis. The soluble (native and unfolded) $\beta$ Lg concentration in the samples was evaluated by HPLC 


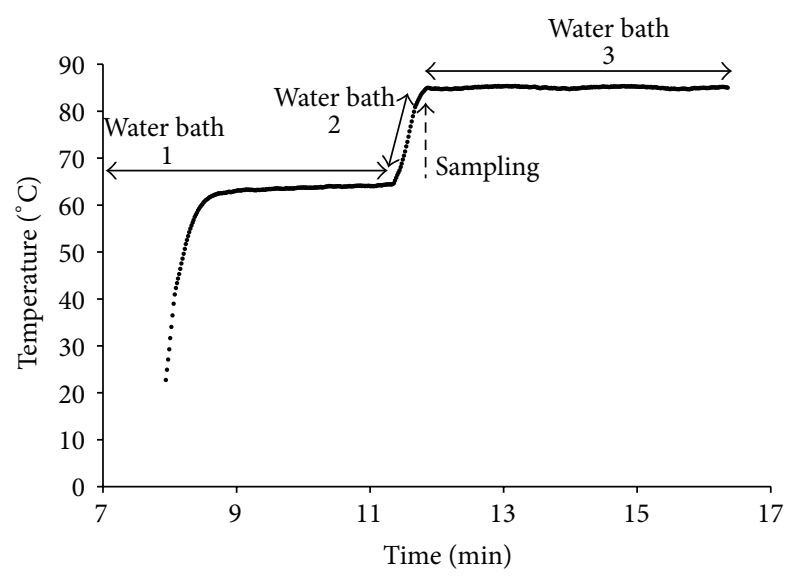

FIGURE 1: Imposed temperature profiles (in the three water baths) to carry out thermal denaturation at a constant holding temperature.

after precipitation of the aggregated protein at $\mathrm{pH} 4.6$ and their removal by centrifugation $(9000 \mathrm{rpm}$ for $30 \mathrm{~min}$ at $4^{\circ} \mathrm{C}$ ). The chromatographic system (Waters, Milford, MA, USA) included a 717 Plus autosampler, a 616 quadratic pump system, a Jones Model 7971 column oven, a CLHP ACE $300 \AA$ C4 separation column and the associated guard column (Advanced Chromatography Technologies, Aberdeen, UK), a 486 UV-visible spectrophotometer, and an acquisition software (Millennium 3.2, Waters).

The mobile phases used in HPLC were $0.1 \%(\mathrm{v} / \mathrm{v})$ trifluoroacetic acid (99\%, Acros Organics, Thermo Fisher Scientific, Waltham, MA, USA) in Milli-Q water and $0.1 \%$ trifluoroacetic acid in a mixture of $80 \%$ acetonitrile (HPLC grade, Thermo Fisher Scientific, Waltham, MA, USA) and $20 \%$ Milli-Q water.

The HPLC analyses were carried out at the following conditions: flow rate $1 \mathrm{~mL} \cdot \mathrm{min}^{-1}$, injection volume $20 \mu \mathrm{L}$, temperature $40^{\circ} \mathrm{C}$, elution of the proteins using a gradient of acetonitrile, and detection of the eluted proteins at wavelength $214 \mathrm{~nm}$. Analyses were repeated three times for each standard or sample. Calibration standards in the range from 0.5 to $4 \mathrm{~g} \cdot \mathrm{L}^{-1}$ were prepared by dissolving $\beta$-Lg powder in Milli-Q water. For each experiment, the sample concentrations were calculated by averaging the three measured chromatographic areas and converting this area value into a $\beta$-Lg concentration using the HPLC calibration curve.

2.4. Determination of the $\beta-L g$ Rate Constants from HPLC Measurements. The reaction model used in this study is derived from the work of Tolkach and Kulozik [18]. The denaturation reaction concerns the transformation of soluble species (noted $S$ ) into aggregates (noted $A$ ) which is described by the chemical equation $S \rightarrow A$ and defined in

$$
-\frac{d C_{S}}{d t}=k_{n} C_{S}^{n}
$$

where $C_{S}$ is the soluble $\beta$-Lg concentration, $k_{n}$ the denaturation rate constant for a reaction order equal to $n$, and $t$ the time.

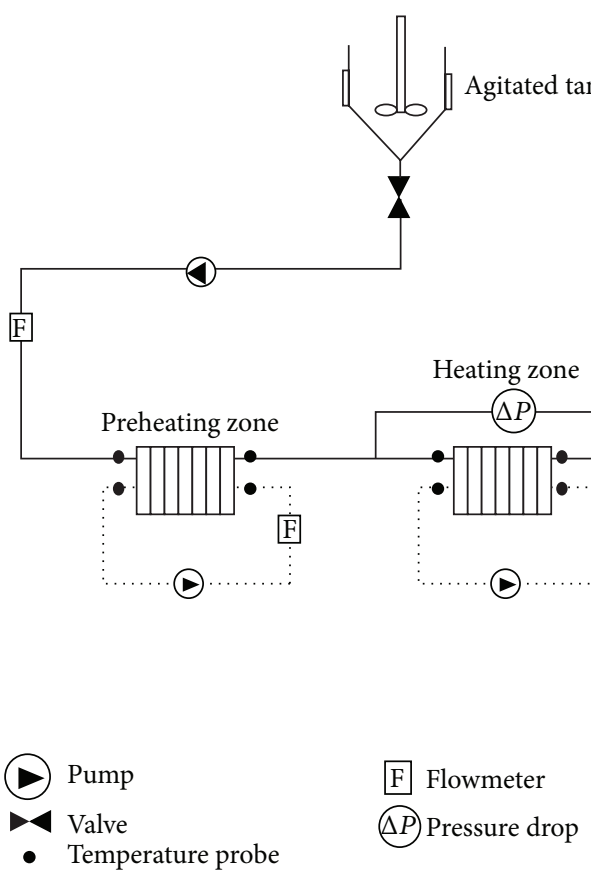

FIGURE 2: Schematic diagram of the experimental setup carried out for fouling runs with the $1 \%(\mathrm{w} / \mathrm{w})$ WPI solutions.

For each temperature, the corresponding denaturation rate constant was determined from the Arrhenius plot. The relation between the denaturation kinetic rate and the heat treatment temperature is given by

$$
\ln \left(k_{n}\right)=\ln \left(k_{n}^{0}\right)-\frac{E_{A}}{R T},
$$

where $k_{n}^{0}$ is the denaturation frequency factor, $E_{A}$ the denaturation activation energy, $R$ the universal gas constant, and $T$ the temperature.

The value of $n$ was varied from 1 to 2 (in steps of 0.1 ) to determine the reaction order that gives the best regression coefficient when plotting $\left(C_{S} / C_{S}^{0}\right)^{1-n}-1$ as a function of time, where $C_{S}^{0}$ is the initial (time zero) $\beta$-Lg total soluble concentration.

The slope of this linear representation is equal to $k_{n}(n-$ 1) $\left(C_{S}^{0}\right)^{n-1}$ and leads to the determination of $k_{n}$. This method was also used by Petit et al. [14], Tolkach and Kulozik [18], and Dannenberg and Kessler [19].

The value of $n=1.5$ reaction order was suitable for the whole $\beta$ - $L$ g denaturation reaction in the investigated temperature range (from 65 to $92^{\circ} \mathrm{C}$ ).

2.5. Fouling Runs and Determination of the Deposit Mass Distribution. Fouling experiments were carried out in a pilot plant (Figure 2). The fouling rig was composed of two distinct zones: (i) a preheating zone composed of a heat exchanger with V7 types plates (Vicarb, Alfa Laval, France) and 9 passes (one channel per pass), necessary to preheat the model fluid, and (ii) a heating zone composed of a PHE (Vicarb, model V7, Alfa Laval, France). 
TABLE 2: Operating conditions investigated with the pilot scale experimental set: mean inlet and outlet temperatures and flow rates of $\beta$-Lg concentrate and hot water.

\begin{tabular}{|c|c|c|c|c|c|}
\hline Thermal profile number & Total calcium content (ppm) & $T_{i p}\left({ }^{\circ} \mathrm{C}\right)$ & $T_{o p}\left({ }^{\circ} \mathrm{C}\right)$ & $Q_{p}\left(\mathrm{~L} \cdot \mathrm{h}^{-1}\right)$ & $Q_{h}\left(\mathrm{~L} \cdot \mathrm{h}^{-1}\right)$ \\
\hline$\# 1$ & 100 & 65 & 85 & 300 & 300 \\
\hline$\# 2$ & 100 & 65 & 85 & 300 & 900 \\
\hline$\# 3$ & 100 & 65 & 85 & 300 & 150 \\
\hline$\# 4$ & 100 & 60 & 75 & 300 & 300 \\
\hline$\# 1$ & 120 & 65 & 85 & 300 & 300 \\
\hline$\# 2$ & 120 & 65 & 85 & 300 & 900 \\
\hline$\# 3$ & 120 & 65 & 85 & 300 & 150 \\
\hline$\# 4$ & 120 & 60 & 75 & 300 & 300 \\
\hline
\end{tabular}

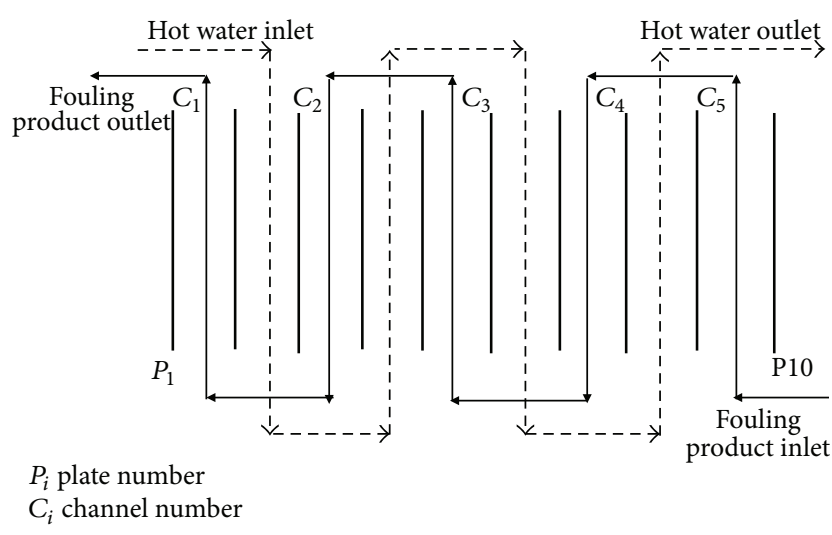

FIGURE 3: Plate heat exchanger flow arrangement.

The PHE setup consisted of 10 plates; that is, 5 passes (one channel per pass) of about $0.074 \mathrm{~m}^{2}$ projected heat transfer area per plate $(0.495 \mathrm{~m}$ length and $0.15 \mathrm{~m}$ width $)$ were installed in a countercurrent configuration to optimize the heat transfer, as represented in Figure 3. The defined design permitted being closer to industrial heat treatment conditions.

The temperature profile inside the heat exchanger was simulated with Sphere software (previously developed at our laboratory): temperatures in all passes of hot and cold fluids were calculated from the knowledge of fluids' inlet temperature and flow rate, plate properties, and heat exchanger design. The temperature profile is controlled by the heat exchanger inlet parameters: product and hot fluid inlet temperatures $\left(T_{i p}\right.$ and $\left.T_{i w}\right)$ and product and hot water flow rates (resp., $Q_{p}$ and $Q_{h}$ ). This was achieved with the operating conditions indicated in Table 2, displaying the average values of temperatures and flow rates recorded during each heat treatment experiment.

The temperature profiles displayed in Figure 4 were obtained by Sphere simulations by employing the operating conditions summarized in Table 2. Eight fouling runs were conducted with WPI solutions containing two calcium concentrations (100 and $120 \mathrm{ppm}$ ).

Heat exchanger plates were weighted before each heat treatment experiment. After being dried in an air oven at

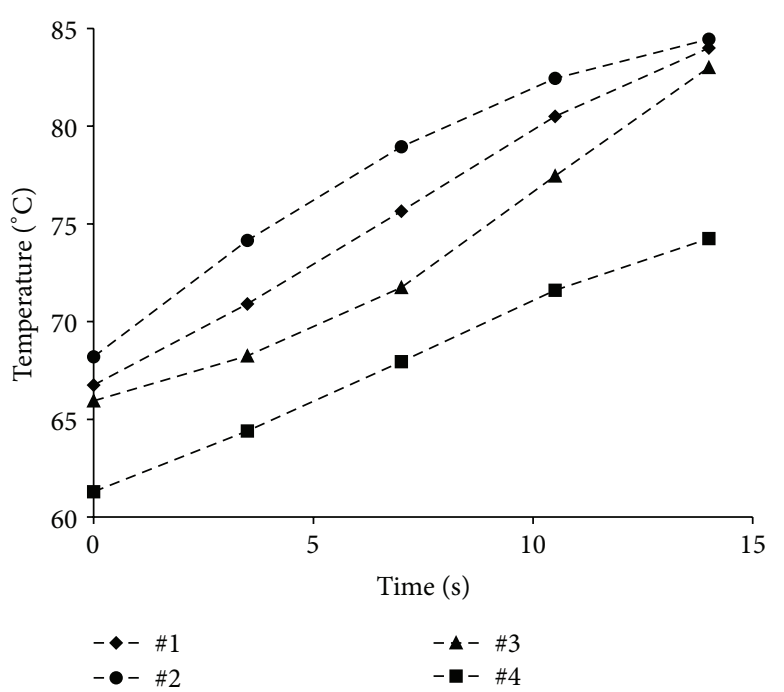

FIGURE 4: The imposed thermal profiles in the PHE (Sphere simulations).

$50^{\circ} \mathrm{C}$, fouled plates were weighted at ambient temperature and the dry deposit mass on each plate was deduced by subtraction.

The amount of fouling was also monitored by calculating the fouling resistance. A linear relationship was visible between the average fouling resistance $R_{f}$, defined by (3), and the fouling thickness, assuming that the deposit layers are covered uniformly:

$$
\frac{1}{U_{g(t)}}=\frac{1}{U_{g(0)}}+R_{f}
$$

where $U_{g(0)}$ and $U_{g(t)}$ are the overall heat transfer coefficients at the beginning of fouling runs (i.e., the overall heat transfer coefficient before the occurrence of fouling) and at time $t$ (i.e., the overall heat transfer coefficient including the additional contribution of fouling).

A logarithmic mean temperature difference (LMTD) method was used to relate the heat transfer rate to the overall heat transfer coefficient. In the case of a no pure 


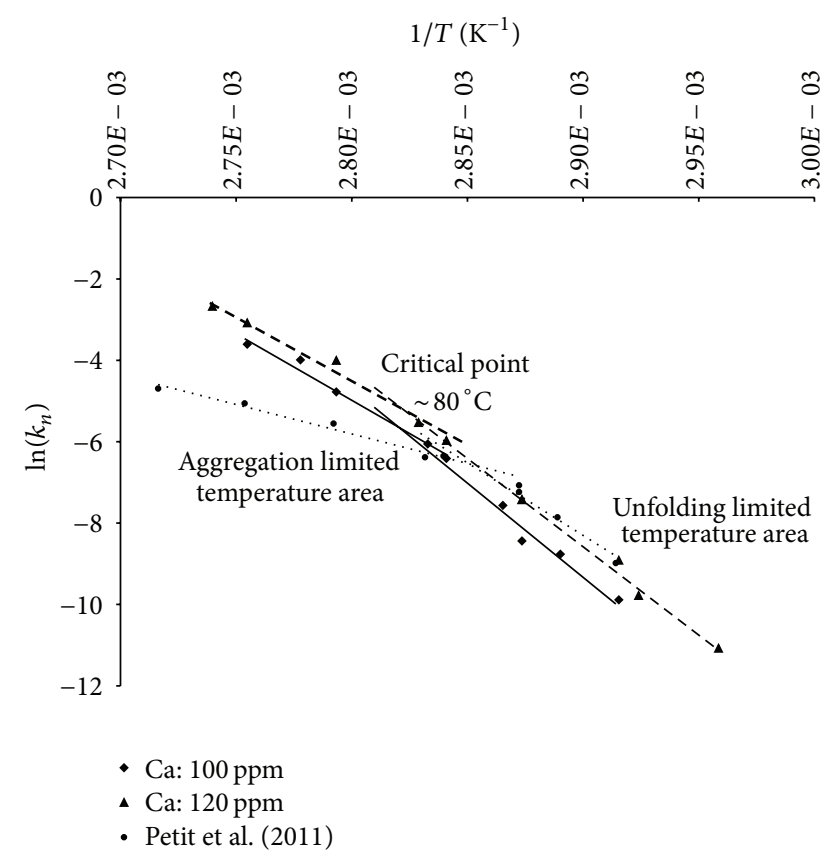

FIGURE 5: Arrhenius plot for the $\beta$-Lg denaturation of $1 \%(w / w)$ WPI fouling solutions at various calcium concentrations (100 and $120 \mathrm{ppm})$.

cross countercurrent flow inside the plate heat exchanger, the correction factor $F_{T}$ is classically introduced:

$$
\begin{aligned}
\dot{m}_{p} C_{p_{p}}\left(T_{o p}-T_{i p}\right) & =\dot{m}_{h} C_{p_{h}}\left(T_{i h}-T_{o h}\right) \\
& =U_{g} S \Delta T_{\mathrm{LMTD}} F_{T}
\end{aligned}
$$

where $C_{p_{p}}$ and $C_{p_{h}}$ are, respectively, the specific heat for the product and hot water, $\dot{m}_{p}$ and $\dot{m}_{h}$ are, respectively, the mass flow rates for the product and hot water, $T$ is the temperature, and $S$ is the heat transfer area.

Leuliet et al. [20] gave equations for PHE using analogy with shell and tube correction factor. Their method was used for this work to evaluate the $F_{T}$ factor.

\section{Results and Discussion}

3.1. Arrhenius Plots for the $\beta$-Lg Denaturation of the Model Solutions. The Arrhenius plots for the denaturation reaction of the WPI model fouling solutions at two calcium concentrations (100 and $120 \mathrm{ppm})$ were presented in Figure 5. This figure shows the temperature influence on the $\beta$-Lg denaturation kinetic rate in the range from 65 to $92^{\circ} \mathrm{C}$.

Two mechanisms appear in Figure 5, separated by an Arrhenius critical temperature of about $80^{\circ} \mathrm{C}$. This slope change suggests two temperature ranges: below the critical temperature, the $\beta$-Lg denaturation reaction is unfolding limited which means that the unfolding reaction is slower than aggregation and over $80^{\circ} \mathrm{C}, \beta-\mathrm{Lg}$ denaturation is limited by the aggregation reaction and in that case, aggregation is the slower reaction.
TABLE 3: Denaturation parameters at the two calcium concentrations.

\begin{tabular}{lcc}
\hline $\begin{array}{l}\text { Denaturation } \\
\text { parameter }\end{array}$ & $100 \mathrm{ppm}$ total calcium & $120 \mathrm{ppm}$ total calcium \\
\hline Unfolding & 124.8 & 117.2 \\
$\ln \left(k_{\mathrm{unf}}^{0}\right)$ & 384.5 & 271.2 \\
$E_{\text {A,unf }}\left(\mathrm{kJ} \cdot \mathrm{mol}^{-1}\right)$ & & \\
Aggregation & 86.3 & 83.1 \\
$\ln \left(k_{\mathrm{agg}}^{0}\right)$ & 360.7 & 260.4 \\
$E_{A, \text { agg }}\left(\mathrm{kJ} \cdot \mathrm{mol}^{-1}\right)$ & & \\
\hline
\end{tabular}

These results are in agreement with Petit et al. [14]. Even in the case of quasi-pure $\beta$-Lg model solution, the critical temperature that splits the Arrhenius plot in two linear parts was estimated at $80^{\circ} \mathrm{C}$, each temperature range being related to the predominance of the unfolding or aggregation mechanisms, indicating that denaturation kinetic rates varied with temperature. However, this slope break is less clear in the case of our model fouling solution, probably due to its more complex composition (mixture of $\beta$-Lg and $\alpha$-lactalbumin).

Figure 5 also shows that $\beta$-Lg denaturation kinetics increased with calcium concentration. Even if the exact contribution of calcium on the denaturation of $\beta-\mathrm{Lg}$ is still unclear, it is speculated that calcium induces protein charge shielding or conformational changes in $\beta$-Lg structure [21, 22] favouring both unfolding and aggregation reactions. This result illustrates that it is essential to know the exact content of calcium in the fouling solutions to have a clear view of the denaturation reaction. This information, not commonly evaluated nowadays in the literature, is essential to the development of accurate model of fouling based on engineering denaturation reaction.

The frequency factor logarithms $\left(\ln k^{0}\right)$ and activation energies $\left(E_{A}\right)$, obtained by fitting Arrhenius plot regression for the unfolding and aggregation denaturation mechanism (noted, resp., unf and agg), are shown in Table 3.

3.2. Fouling Mass Distribution in the PHE. Figure 6 represents the deposit layer formed in the first and last channels of the $\mathrm{PHE}$, at, respectively, $65^{\circ} \mathrm{C}$ (inlet temperature) and $85^{\circ} \mathrm{C}$ (outlet temperature), after fouling run conducted with $1 \%$ (w/w) WPI solution containing $100 \mathrm{ppm}$ of total calcium. At the highest temperature, the fouling layer is white, very thick, and homogeneous. It clearly appears that very low fouling is obtained in the first channel of the PHE, where the bulk temperature is lower than $70^{\circ} \mathrm{C}$. Fouling is not expected to occur under $65-72^{\circ} \mathrm{C}[23,24]$. These observations are in agreement with Foster et al. [25] work, which showed that deposit increases with temperature, making fouling rougher and more adherent to hot surfaces.

Figure 7 represents the fouling results obtained with $1 \%$ (w/w) WPI model solution containing 100 and $120 \mathrm{ppm}$ of total calcium at different temperature profiles. This figure shows that the dry deposit is not uniform and is distributed differently depending on the thermal profile and the calcium 


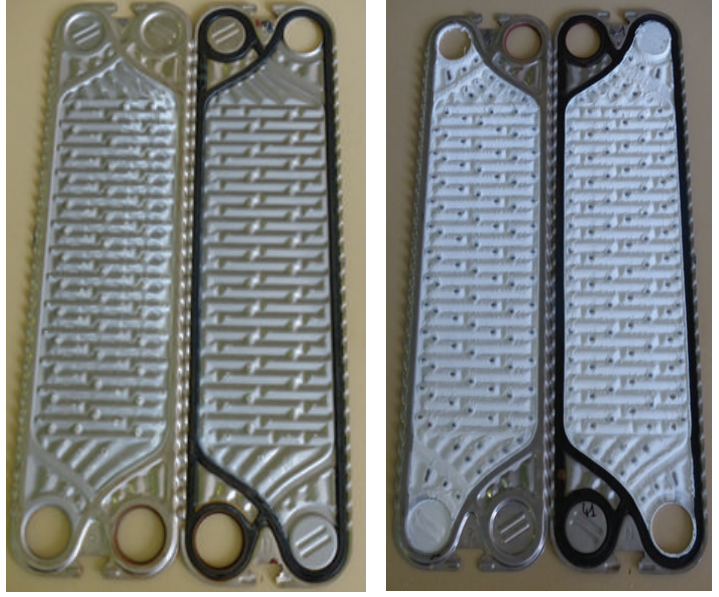

FIGURE 6: Pictures of the deposit collected on heat exchanger surface in the second and last channels of the PHE.

concentration. Indeed, for the first solution at $100 \mathrm{ppm}$ calcium, the deposit mass increases linearly to reach a maximum in the 5th channel, whatever the imposed thermal profile. However, at $120 \mathrm{ppm}$ calcium, the deposit mass reached a stationary value of about $260 \mathrm{~g} / \mathrm{m}^{2}$ over $74^{\circ} \mathrm{C}$ (2nd channel temperature), for the first three temperature profiles, which consisted in a fouling maximum limit. This increasing deposit mass at low temperatures resulted from the strong increase of $\beta$-Lg denaturation level between $65^{\circ} \mathrm{C}$ (1st channel temperature) and $74^{\circ} \mathrm{C}$ (2nd channel temperature), temperature range for which the $\beta$-Lg denaturation reaction becomes significant $[17,26]$. The thermal profile \#4 increases linearly, reaching a maximum of $84.5 \mathrm{~g} / \mathrm{m}^{2}$ in the 5 th channel.

The deposit mass is negligible, for the thermal profile \#4 at 100 and $120 \mathrm{ppm}$ calcium, owing to the lack of denatured $\beta$-Lg in the bulk at such low temperatures. It is suggested that $\beta$-Lg fouled hot surfaces only when the bulk temperature was high enough to allow $\beta$-Lg denaturation.

Figure 8 represents the effect of the temperature profile on the total amount of deposit mass in the PHE for the two fouling solutions. It can be observed that, for the same inlet and outlet product temperature, the total deposit mass varied with the calcium concentration. This is the case of the thermal profile \#1, for which the total deposit mass goes from $1415 \mathrm{~g} / \mathrm{m}^{2}$ at $100 \mathrm{ppm}$ calcium to $2082 \mathrm{~g} / \mathrm{m}^{2}$ at $120 \mathrm{ppm}$ calcium. This was also observed for the temperature profiles $\# 3$ and \#4. However, for the thermal profile \#2, the total amount of deposit was very close at 100 and 120 ppm calcium.

This difference of fouling distributions obtained at various calcium concentrations demonstrates the major role of the temperature profile on $\beta$ - $\operatorname{Lg}$ fouling and its distribution in the PHE.

\subsection{Effect of Thermal Profiles and Calcium Concentration} on Fouling Rate. Figure 9 shows the fouling rate behaviour during heating of the WPI solution at 100 and $120 \mathrm{ppm}$ calcium in the PHE, for each thermal profile. An increase in the fouling rate with time is evident. A difference between the fouling rates can be observed for the four temperature profiles, at $100 \mathrm{ppm}$ and $120 \mathrm{ppm}$ calcium.

The results also show that the fouling potential of WPI in the PHE increases with the increasing temperature. Indeed, for temperature range of $65-85^{\circ} \mathrm{C}$, fouling rate is altered and favoured by higher amount of calcium in the model fluid. It can be noted that, for the thermal profile \#4 (60$75^{\circ} \mathrm{C}$ ), fouling resistance curves for calcium content of 100 and $120 \mathrm{ppm}$ calcium were superposed. These results are not contradictory with the assumption of Daufin et al. [27], Xiong [28], and Simons et al. [21], who asserted that calcium can interact with the aspartic and glutamic acid carboxyl group of the $\beta$-Lg and so favour the growth of the deposit by stabilizing protein aggregates. This is because calcium ions form bridges between adsorbed proteins and the protein aggregates occurring in the bulk, consequently modifying the protein aggregation rate and leading to a greater cohesion between the protein aggregates which in turn change the deposit structure [29]. Simmons et al. [30] revealed an increase in deposition upon a Couette surface due to calcium ions and a modification in the appearance of the deposit for a temperature range $75-90^{\circ} \mathrm{C}$. In addition, Pappas and Rothwell [31] showed that $\beta$-Lg completely aggregated to form compact structures when heated with calcium from 80 to $110^{\circ} \mathrm{C}$.

\subsection{Relationship between $\beta$-Lg Heat Denaturation Rate Con-} stants and the Distribution of the Deposit Mass along the PHE. To study the relationship between the chemical reaction of the $\beta$-Lg denaturation and the deposit formation rate within the $\mathrm{PHE}$, the deposit mass distribution in the different channel of the PHE was plotted against $r=k_{\text {unf }} / k_{\text {agg }}$ (Figure 10). The value of $r$ was calculated at the average temperature of the channel. $k_{\text {unf }}$ and $k_{\text {agg }}$ represent, respectively, the reaction rate constants for the unfolding and aggregation limited zones deduced from the Arrhenius plots (Figure 5) for the two WPI model fouling solutions (at 100 and 120 ppm of calcium).

For each fouling solution, it could be observed that an $S$ curve (plot of the deposit mass per channel versus $r$ ) consolidates the fouling data, whatever the imposed thermal profile. The $S$ curves could be described, for all fouling runs, by the following function:

$$
M_{d}=a+\frac{b-a}{1+(c / r)^{d}},
$$

where $M_{d}$ is the measured dry fouling deposit mass per channel along the PHE and $a, b, c$, and $d$ are four constants.

The two master curves, representing the deposit mass per channel versus the ratio $r$, contained different characteristic zones:

(i) an unfolding limited zone with a sharp increase of the deposit mass per channel with $r$;

(ii) an aggregation limited zone where the deposit mass per channel seems to reach a limiting value.

Indeed, the curve of the dry deposit mass at 100 ppm calcium showed a sharp increase at values of $r$ close to 0.22 (relative 


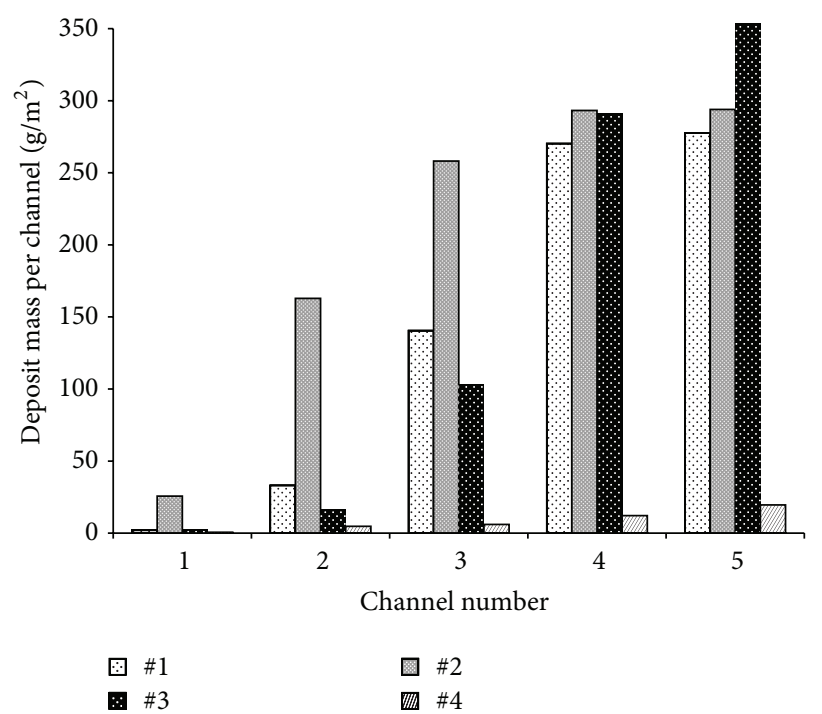

(a)

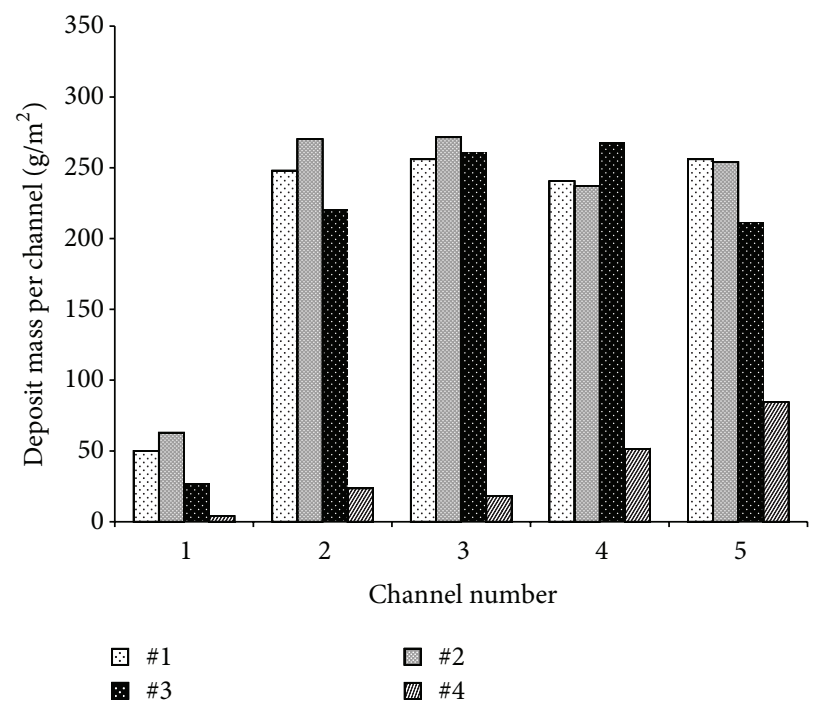

(b)

FIGURE 7: Fouling mass distribution, related to the projected heat transfer area per plaque, in each channel of the PHE for the two fouling solutions. 1\% (w/w) WPI solution containing (a) $100 \mathrm{ppm}$ calcium and (b) $120 \mathrm{ppm}$ calcium (\#i corresponds to the thermal profile number given in Figure 4 and Table 2).

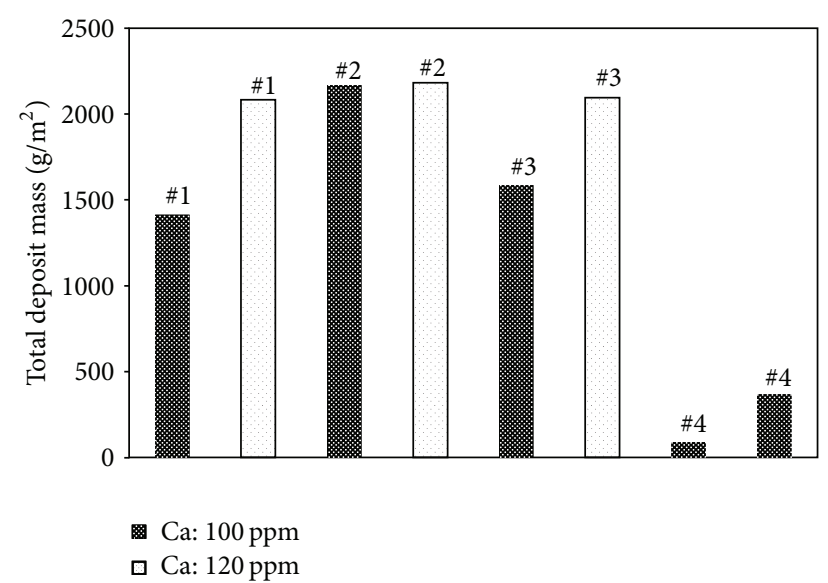

Figure 8: Total amount of the deposit mass in the PHE per unit area for $1 \%(\mathrm{w} / \mathrm{w})$ WPI fouling solutions at various calcium concentrations (100 and $120 \mathrm{ppm}$ ) and for different temperature profiles (\#i corresponds to the thermal profile number given in Figure 4 and Table 2).

to the fouling beginning), then reaching a plateau at $r=0.91$. For the second fouling solution (WPI solution containing $120 \mathrm{ppm}$ of calcium), the increase of $r$ values starts at 0.23 and the maximum of the deposit mass is reached at $r=0.67$.

In summary, for the two fouling model solutions and the operating conditions investigated, it can be observed that a sharp increase of deposit mass occurs, when $r$ is located between 0.22 and 0.89 (corresponding to bulk temperatures ranging from 65 to $80.5^{\circ} \mathrm{C}$ ). The fact that the deposit mass increases strongly, when $r$ is below 1 , shows that the unfolding limited zone controls the growth of the deposit mass. This result also shows that the deposit mass per channel decreases

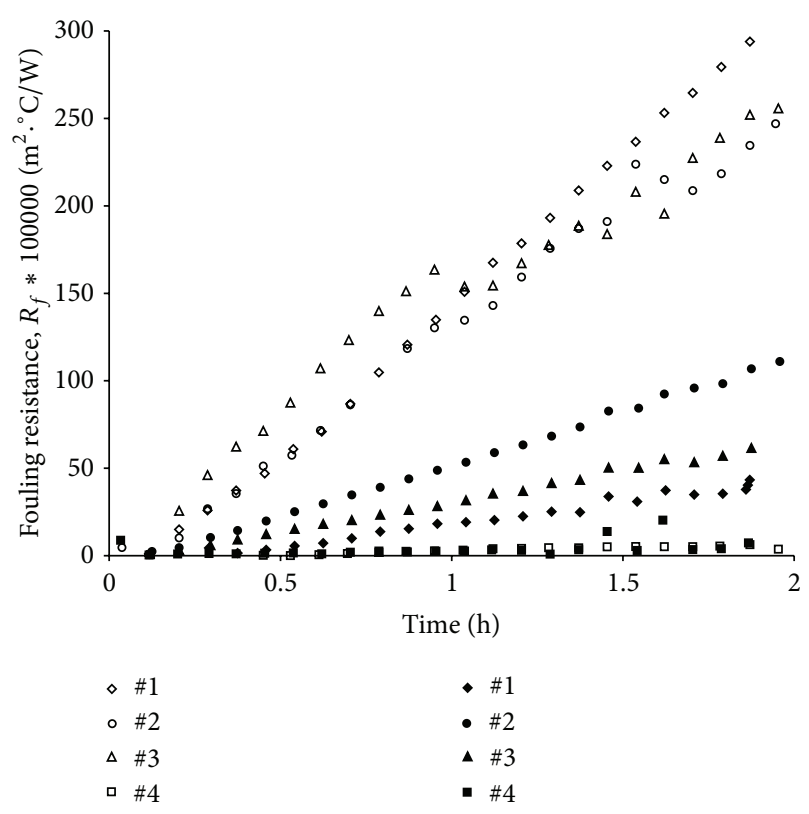

FIGURE 9: Fouling resistance evolution with time measured along the PHE. Various symbols refer to various fouling runs with varying thermal profiles and various calcium content for the $1 \% \mathrm{w} / \mathrm{w}$ WPI solutions (closed symbols: 100 ppm calcium; open symbols: 120 ppm calcium) (\#i corresponds to the thermal profile number given in Figure 4 and Table 2).

when the aggregation reaction is high enough to consume the unfolded species under aggregates forms. This result is in agreement with the previous observation of van Asselt et al. [13] and consistent with the work of Blanpain-Avet et al. [32]. Indeed, these authors conclude from fouled deposit 


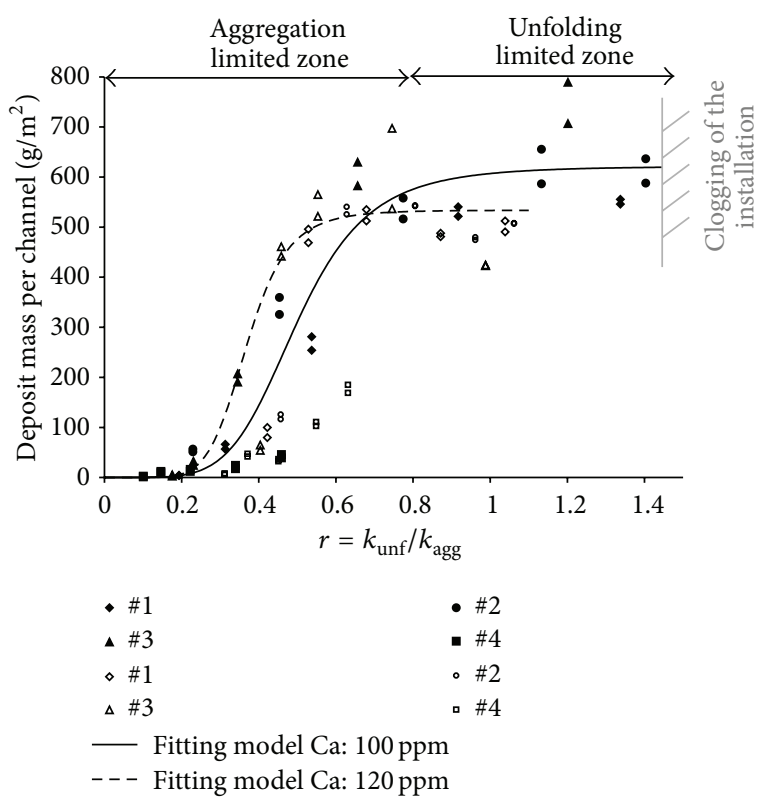

Figure 10: Plots of the dry deposit masses per unit area versus the ratio of unfolding and aggregation rate constants for the $1 \% \mathrm{w} / \mathrm{w}$ WPI solutions (closed symbols: $100 \mathrm{ppm}$ calcium; open symbols: $120 \mathrm{ppm}$ calcium) ( $\# i$ corresponds to the thermal profile number given in Figure 4 and Table 2).

analysis by Raman spectroscopy that protein aggregates are not present in the deposit. This result is also supported by the recent study of Bouvier et al. [33] which showed that a correlation can be established between the unfolded $\beta$-Lg content within the PHE and the dry deposit mass distribution.

Unfortunately, it was not possible to perform pilot scale experiments at higher values of $r(r>1.40)$, corresponding to the channel temperature above $84.4^{\circ} \mathrm{C}$, because of the clogging of the installation.

To ascertain validity of the master curve independently of the PHE configuration, further experiments were conducted at PHE consisting of 10 passes (one channel per pass) for a $1 \%$ $(\mathrm{w} / \mathrm{w})$ WPI model solution at $100 \mathrm{ppm}$ calcium. One thermal profile (\#1), out of the four tested for the five channels of the PHE, was imposed. Figure 11 represents the deposit mass per channel versus the ratio $r$.

Also in this case, the fouling mass is reasonably well correlated to the ratio $r$ showing the following:

(i) the importance of determining this indicator for predicting fouling mass distribution;

(ii) the robustness of the approach.

\section{Conclusions}

Fouling experiments were performed with $1 \%(\mathrm{w} / \mathrm{w})$ WPI solutions, at two different calcium concentrations, in order to investigate the effect of the operating conditions associated with the chemical denaturation reactivity of heat treatment in a PHE on the deposit formation. The extent of fouling

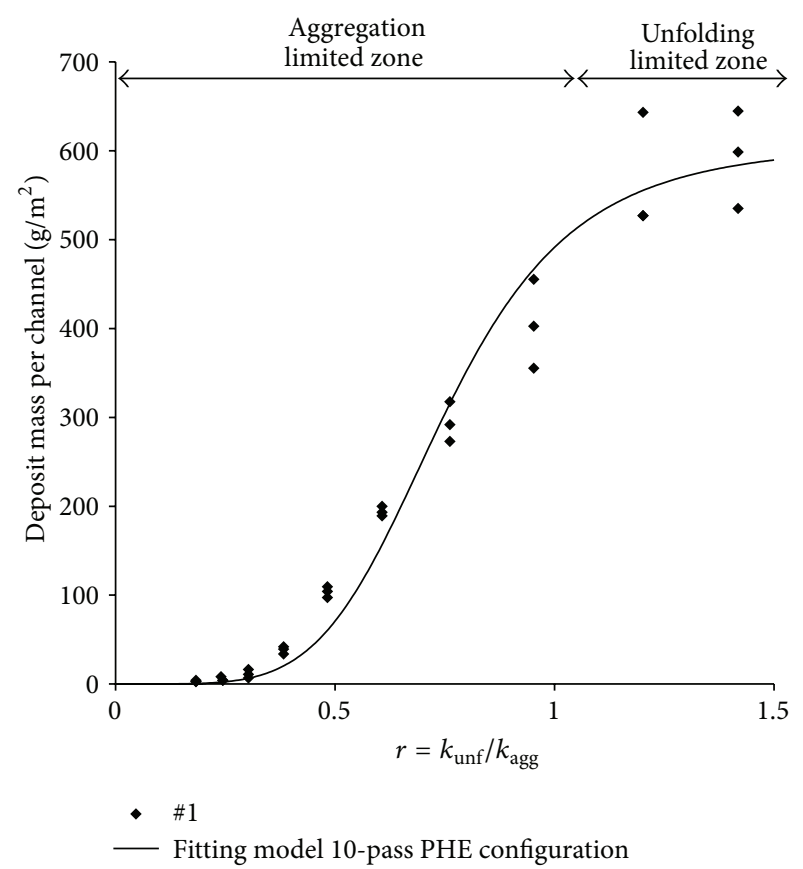

FIGURE 11: Variation of the dry deposit mass per unit area in the various channels with the ratio $r$ for a 10-pass PHE configuration (\#1 corresponds to the thermal profile given in Figure 4 and Table 2).

deposit was monitored by weighing the mass of the dry fouling deposit on the plates.

It was shown that

(i) $\beta$-Lg denaturation is a complex process with a twostep mechanism highly dependent on the calcium content;

(ii) an increase of the calcium content in the fouling solution induced a strong increase in the $\beta$ - Lg denaturation level and consequently in the fouling mass within the PHE at high temperatures;

(iii) the fouling mass distribution also depends on the thermal profiles imposed on the fouling solutions;

(iv) the dry deposit mass on each pass of the PHE seems to be correlated with $r=k_{\text {unf }} / k_{\text {agg }}$. This observation indicates that the knowledge of this parameter is important to predict the mass distribution of the fouling deposit.

This work clearly shows that $\beta$ - $\mathrm{Lg}$ competitive reactions (unfolding and aggregation) governing the growth of fouling for a WPI solution and the identification of the heat-induced denaturation kinetic by means of laboratory experiments are prerequisites to control fouling. We encourage strongly the fouling community to develop database on these aspects to be able to predict the distribution of fouling mass whatever the imposed temperature profile and to mitigate fouling. 


\section{Nomenclature}

\begin{tabular}{|c|c|}
\hline$a:$ & $\begin{array}{l}\text { Adjusted parameter in the nonlinear regression } \\
\text { using (5) }\end{array}$ \\
\hline$b:$ & $\begin{array}{l}\text { Adjusted parameter in the nonlinear regression } \\
\text { using (5) }\end{array}$ \\
\hline$c:$ & $\begin{array}{l}\text { Adjusted parameter in the nonlinear regression } \\
\text { using (5) }\end{array}$ \\
\hline Ca: & Calcium concentration, ppm \\
\hline$C_{S}:$ & Concentration of the total soluble $\beta$ - $\mathrm{Lg}, \mathrm{g} \mathrm{L}^{-1}$ \\
\hline$C_{p_{p}}:$ & Specific heat for the product, $\mathrm{J} \mathrm{kg}^{-1} \mathrm{~K}^{-1}$ \\
\hline$C_{p_{h}}:$ & Specific heat for the hot water, $\mathrm{J} \mathrm{kg}^{-1} \mathrm{~K}^{-1}$ \\
\hline$d:$ & $\begin{array}{l}\text { Adjusted parameter in the nonlinear regression } \\
\text { using (5) }\end{array}$ \\
\hline$E_{A}:$ & Activation energy, $\mathrm{J} \mathrm{mol}^{-1}$ \\
\hline$E_{A, \text { agg }}:$ & $\beta$-Lg aggregation activation energy, $\mathrm{J} \mathrm{mol}^{-1}$ \\
\hline$E_{A, \text { unf }}:$ & $\beta$-Lg unfolding activation energy, $\mathrm{J} \mathrm{mol}^{-1}$ \\
\hline$F_{T}:$ & Logarithmic mean temperature difference, - \\
\hline$k_{n}:$ & Denaturation rate constant, $\mathrm{g}^{1-n} \mathrm{~L}^{n-1} \mathrm{~s}^{-1}$ \\
\hline$k_{n}^{0}:$ & Denaturation frequency factor, $\mathrm{g}^{1-n} \mathrm{~L}^{n-1} \mathrm{~s}^{-1}$ \\
\hline$k_{\text {unf }}:$ & Unfolding rate constant, $\mathrm{g}^{1-n} \mathrm{~L}^{n-1} \mathrm{~s}^{-1}$ \\
\hline$k_{\mathrm{agg}}$ : & Aggregation rate constant, $\mathrm{g}^{1-n} \mathrm{~L}^{n-1} \mathrm{~s}^{-1}$ \\
\hline$M_{d}$ & $\begin{array}{l}\text { Measured dry fouling deposit mass in a channel } \\
\text { along the PHE, } g\end{array}$ \\
\hline$\dot{m}_{p}:$ & Mass flow rates for the product, $\mathrm{kg} \mathrm{s}^{-1}$ \\
\hline$\dot{m}_{h}:$ & Mass flow rates for the hot water, $\mathrm{kg} \mathrm{s}^{-1}$ \\
\hline$n:$ & Heat-induced denaturation reaction order \\
\hline$Q_{p}:$ & WPI fouling solution flow rate, $\mathrm{L} \mathrm{h}^{-1}$ \\
\hline$Q_{h}:$ & Hot water flow rate, $\mathrm{L} \mathrm{h}^{-1}$ \\
\hline$r:$ & $\begin{array}{l}\text { Ratio between the unfolding and aggregation rate } \\
\text { constants, - }\end{array}$ \\
\hline$R:$ & $\begin{array}{l}\text { The universal gas constant equal to } 8.314 \text {, } \\
\mathrm{J} \mathrm{mol}^{-1} \mathrm{~K}^{-1}\end{array}$ \\
\hline$R_{f}:$ & Fouling resistance, $\mathrm{m}^{2 \circ} \mathrm{CW}^{-1}$ \\
\hline$S:$ & Heat transfer area, $\mathrm{m}^{2}$ \\
\hline$T_{i h}:$ & Hot water temperature at the PHE inlet, $\mathrm{K}$ \\
\hline$T_{i p}:$ & $\begin{array}{l}\text { WPI fouling solution temperature at the PHE } \\
\text { inlet, } \mathrm{K}\end{array}$ \\
\hline$T_{o h}:$ & Hot water temperature at the PHE outlet, K \\
\hline$T_{o p}:$ & Hot water temperature at the PHE outlet, $\mathrm{K}$ \\
\hline$U_{g}:$ & Overall heat transfer coefficient, $\mathrm{W} \mathrm{m}^{-2} \mathrm{~K}^{-1}$ \\
\hline
\end{tabular}

$\triangle T_{\text {LMTD }}$ : Logarithmic mean temperature difference, $\mathrm{K}$.

\section{Subscript}

$$
\begin{array}{ll}
\text { agg: } & \text { Aggregation } \\
C_{i}: & \text { Channel number } \\
h: & \text { Hot water } \\
p: & \text { Product } \\
P_{i}: & \text { Plate number } \\
\text { PHE: } & \text { Plate heat exchanger } \\
\text { unf: } & \text { Unfolding } \\
\text { WPI: } & \text { Whey protein isolate } \\
\alpha \text {-La: } & \alpha \text {-lactalbumin } \\
\beta \text {-Lg: } & \beta \text {-lactoglobulin } \\
\# i: & \text { Thermal profile number. }
\end{array}
$$

\section{Conflict of Interests}

The authors declare that there is no conflict of interests regarding the publication of this paper.

\section{Acknowledgments}

The authors are indebted to the Scientific Committee of Agrocampus Ouest Rennes and HEI (Hautes Etudes d'Ingénieur, Lille) for stimulating discussions and financial support for the $\mathrm{Ph} . \mathrm{D}$. Thesis of the first author.

\section{References}

[1] D. M. Mulvihill and M. Donovan, "Whey proteins and their thermal denaturation-a review," Irish Journal of Food Science and Technology, vol. 11, no. 1, pp. 43-75, 1987.

[2] N. Sava, I. Van der Plancken, W. Claeys, and M. Hendrickx, "The kinetics of heat-induced structural changes of $\beta$-lactoglobulin," Journal of Dairy Science, vol. 88, no. 5, pp. 1646-1653, 2005.

[3] C. Schmitt, C. Bovay, M. Rouvet, S. Shojaei-Rami, and E. Kolodziejczyk, "Whey protein soluble aggregates from heating with $\mathrm{NaCl}$ : physicochemical, interfacial, and foaming properties," Langmuir, vol. 23, no. 8, pp. 4155-4166, 2007.

[4] B. Bansal and X. D. Chen, "A critical review of milk fouling in heat exchangers," Comprehensive Reviews in Food Science and Food Safety, vol. 5, no. 2, pp. 27-33, 2006.

[5] S. N. Tay and C. Yang, Assessment of the Hydro-Ball Condenser Tube Cleaning System, HydroBall Technics (SEA) Pte, Singapore, 2006.

[6] H. M. Müller-Steinhagen, Handbook of Heat Exchanger Fouling: Mitigation and Cleaning Technologies, Publico Publications, Essen, Germany; Institution of Chemical Engineers, Rugby, UK, 2000.

[7] M. Lalande and J. P. Tissier, "Fouling of heat transfer surfaces related to $\beta$-lactoglobulin denaturation during heat processing of milk," Biotechnology Progress, vol. 1, no. 2, pp. 131-139, 1985.

[8] P. De Jong, R. Waalewijn, and H. J. L. J. Van Der Linden, "Validity of a kinetic fouling model for heat-treatment of whole milk," Le Lait, vol. 73, no. 3, pp. 293-302, 1993.

[9] S. D. Changani, M. T. Belmar-Beiny, and P. J. Fryer, "Engineering and chemical factors associated with fouling and cleaning in milk processing," Experimental Thermal and Fluid Science, vol. 14, no. 4, pp. 392-406, 1997.

[10] H. Burton, "Properties of UHT-processed milk," in Ultra-High Temperature Processing of Milk and Milk Products, pp. 254-291, Elsevier Applied Science Publishers, 1988.

[11] M. T. Belmar-Beiny, S. M. Gotham, W. R. Paterson, P. J. Fryer, and A. M. Pritchard, "The effect of Reynolds number and fluid temperature in whey protein fouling," Journal of Food Engineering, vol. 19, no. 2, pp. 119-139, 1993.

[12] P. J. R. Schreier and P. J. Fryer, "Heat exchanger fouling: a model study of the scaleup of laboratory data," Chemical Engineering Science, vol. 50, no. 8, pp. 1311-1321, 1995.

[13] A. J. van Asselt, M. M. M. Vissers, F. Smit, and P. de Jong, "Inline control of fouling," in Proceedings of the Heat Exchanger Fouling and Cleaning-Challenges and Opportunities, Engineering Conferences International, Irsee, Germany, June 2005.

[14] J. Petit, A.-L. Herbig, A. Moreau, and G. Delaplace, "Influence of calcium on $\beta$-lactoglobulin denaturation kinetics: implications 
in unfolding and aggregation mechanisms," Journal of Dairy Science, vol. 94, no. 12, pp. 5794-5810, 2011.

[15] M. Khaldi, P. Blanpain-Avet, R. Guérin et al., "Effect of calcium content and flow regime on whey protein fouling and cleaning in a plate heat exchanger," Journal of Food Engineering, vol. 147, pp. 68-78, 2015.

[16] B. T. Nielsen, H. Singh, and J. M. Latham, "Aggregation of bovine $\beta$-lactoglobulins A and $\mathrm{B}$ on heating at $75^{\circ} \mathrm{C}$," International Dairy Journal, vol. 6, no. 5, pp. 519-527, 1996.

[17] H. Lindmark-Månsson, A. Timgren, G. Aldén, and M. Paulsson, "Two-dimensional gel electrophoresis of proteins and peptides in bovine milk," International Dairy Journal, vol. 15, no. 2, pp. 111-121, 2005.

[18] A. Tolkach and U. Kulozik, "Reaction kinetic pathway of reversible and irreversible thermal denaturation of $\beta$ lactoglobulin," Dairy Science and Technology, vol. 87, no. 4-5, pp. 301-315, 2007.

[19] F. Dannenberg and H. G. Kessler, "Reaction kinetics of the denaturation of whey proteins in milk," Journal of Food Science, vol. 53, no. 1, pp. 258-263, 1988.

[20] J. C. Leuliet, J. F. Maingonnat, and M. Lalande, "Thermal behaviour of plate heat exchangers with Newtonian and nonNewtonian fluids," in Proceedings of the Congres Eurotherm 5 et ler Colloque TIFAN, pp. 1-15, Compiegne, France, 1988.

[21] J.-W. F. A. Simons, H. A. Kosters, R. W. Visschers, and H. H. J. de Jongh, "Role of calcium as trigger in thermal $\beta$-lactoglobulin aggregation," Archives of Biochemistry and Biophysics, vol. 406, no. 2, pp. 143-152, 2002.

[22] B. T. O'Kennedy and J. S. Mounsey, “The dominating effect of ionic strength on the heat-induced denaturation and aggregation of $\beta$-lactoglobulin in simulated milk ultrafiltrate," International Dairy Journal, vol. 19, no. 3, pp. 123-128, 2009.

[23] M. Lalande, F. Rene, and J.-P. Tissier, "Fouling and its control in heat exchangers in the dairy industry," Biofouling, vol. 1, no. 3, pp. 233-250, 1989.

[24] J. Visser and T. J. M. Jeurnink, "Fouling of heat exchangers in the dairy industry," Experimental Thermal and Fluid Science, vol. 14, no. 4, pp. 407-424, 1997.

[25] C. L. Foster, M. Britten, and M. L. Green, "A model heatexchange apparatus for the investigation of fouling of stainless steel surfaces by milk. I. Deposit formation at $100^{\circ} \mathrm{C}$," Journal of Dairy Research, vol. 56, no. 2, pp. 201-209, 1989.

[26] P. Havea, H. Singh, and L. K. Creamer, "Characterization of heat-induced aggregates of $\beta$-lactoglobulin, $\alpha$-lactalbumin and bovine serum albumin in a whey protein concentrate environment," Journal of Dairy Research, vol. 68, no. 3, pp. 483497, 2001.

[27] G. Daufin, J. P. Labbé, A. Quemerais et al., "Fouling of a heat exchange surface by whey, milk and model fluids: an analytical study," Le Lait, vol. 67, no. 3, pp. 339-364, 1987.

[28] Y. L. Xiong, "Influence of $\mathrm{pH}$ and ionic environment on thermal aggregation of whey proteins," Journal of Agricultural and Food Chemistry, vol. 40, no. 3, Article ID 91-5-154, pp. 380-384, 1992.

[29] T. Phan-Xuan, D. Durand, T. Nicolai, L. Donato, C. Schmitt, and L. Bovetto, "Tuning the structure of protein particles and gels with calcium or sodium ions," Biomacromolecules, vol. 14, no. 6, pp. 1980-1989, 2013.

[30] M. J. H. Simmons, P. Jayaraman, and P. J. Fryer, "The effect of temperature and shear rate upon the aggregation of whey protein and its implications for milk fouling," Journal of Food Engineering, vol. 79, no. 2, pp. 517-528, 2007.
[31] C. P. Pappas and J. Rothwell, "The effects of heating, alone or in the presence of calcium or lactose, on calcium binding to milk proteins," Food Chemistry, vol. 42, no. 2, pp. 183-201, 1991.

[32] P. Blanpain-Avet, A. Hédoux, Y. Guinet et al., "Analysis by Raman spectroscopy of the conformational structure of whey proteins constituting fouling deposits during the processing in a heat exchanger," Journal of Food Engineering, vol. 110, no. 1, pp. 86-94, 2012.

[33] L. Bouvier, A. Moreau, G. Ronse, T. Six, J. Petit, and G. Delaplace, "A CFD model as a tool to simulate $\beta$-lactoglobulin heat-induced denaturation and aggregation in a plate heat exchanger," Journal of Food Engineering, vol. 136, pp. 56-63, 2014. 

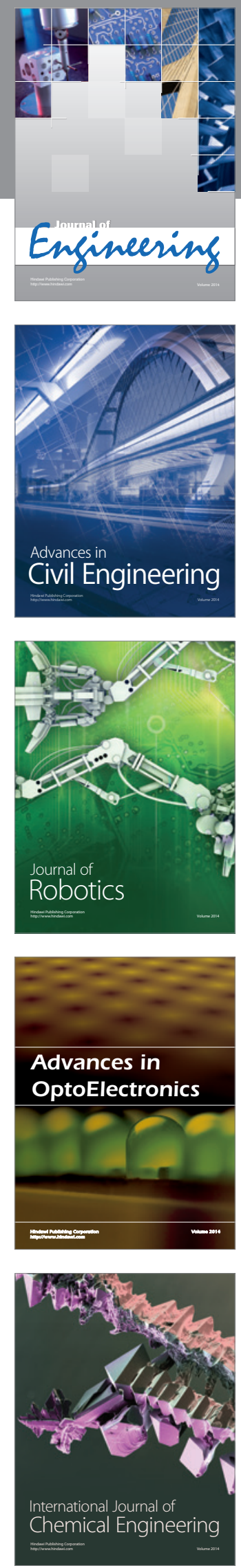

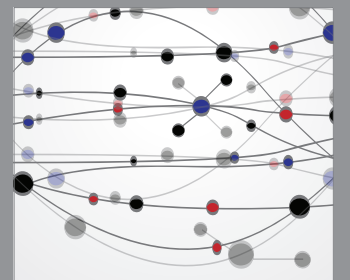

The Scientific World Journal
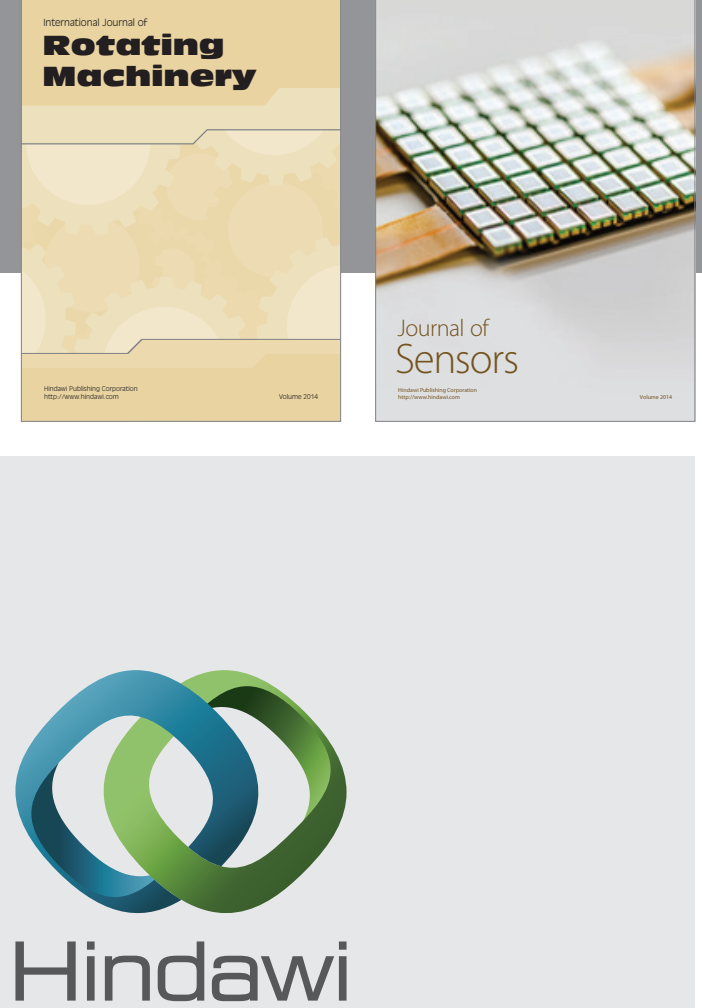

Submit your manuscripts at http://www.hindawi.com
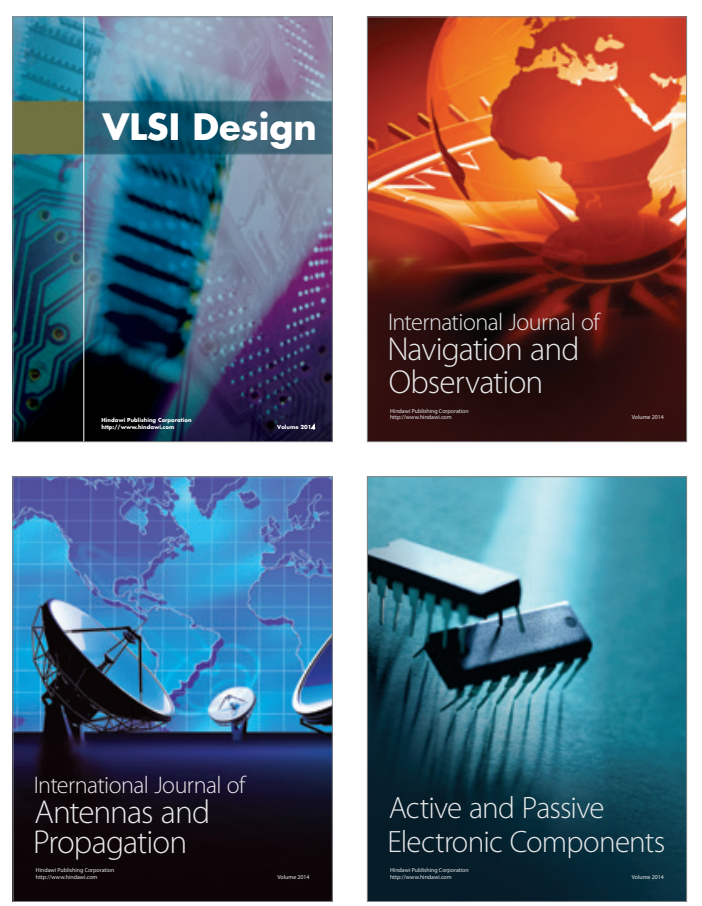
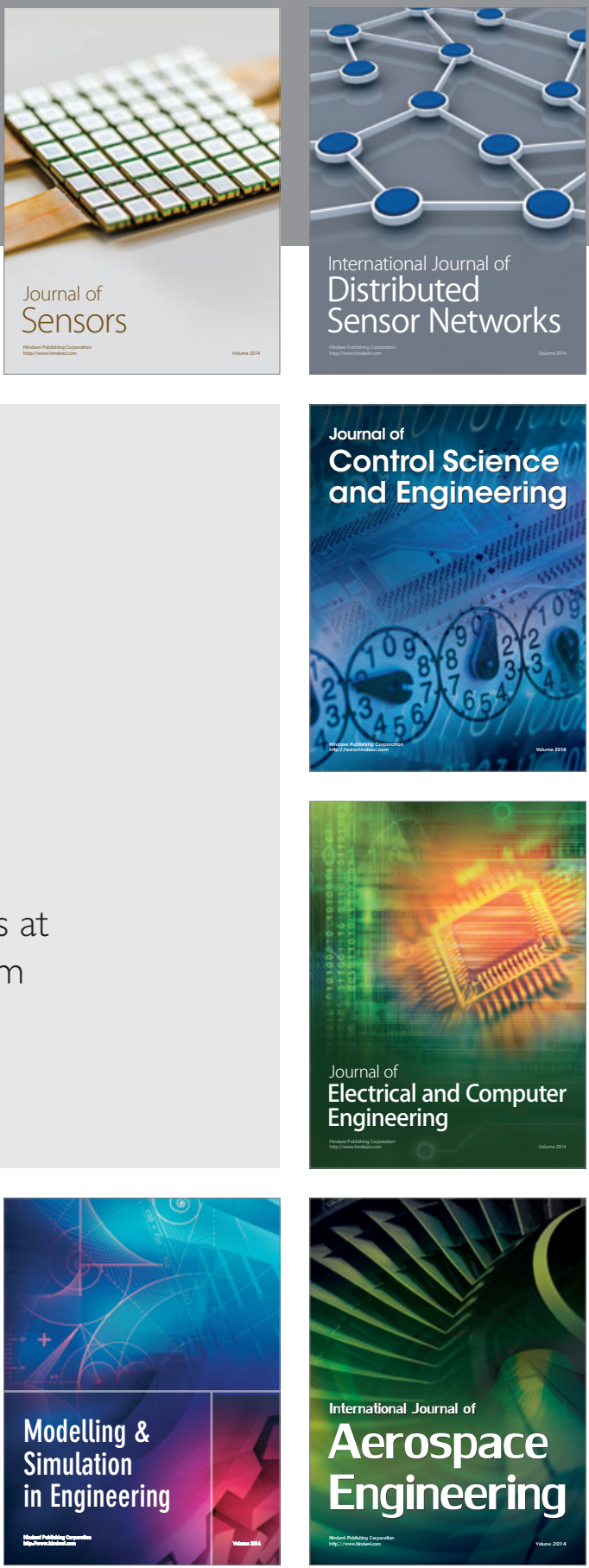

Journal of

Control Science

and Engineering
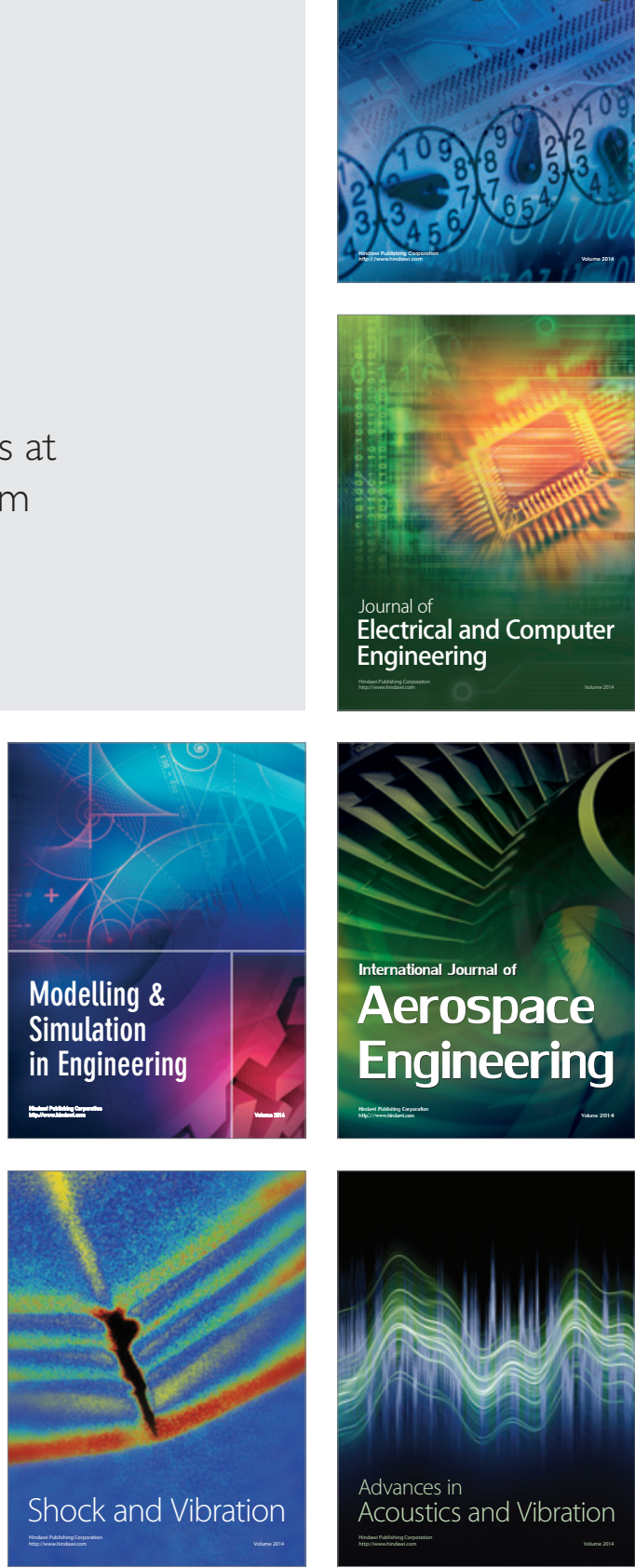